\title{
Carrier detection in the testicular feminisation syndrome: deficient $5 \alpha$-dihydrotestosterone binding in cultured skin fibroblasts from the mothers of patients with complete androgen insensitivity
}

\author{
M B HODGINS, E M C DUKE*, AND DOROTHY RING \\ From the Department of Dermatology, University of Glasgow, and *Department of Child Health, \\ The Royal Hospital for Sick Children, Yorkhill, Glasgow.
}

SUMMARY Specific binding of $5 \alpha$-dihydrotestosterone (androgen receptor activity) could not be윽 detected in cultured genital skin fibroblasts (GSF) from two patients with complete androgen $\vec{c}$ insensitivity (CAI). In GSF from the mother of one patient, androgen receptor activity $(8 \cdot 5 \mathrm{fmol} / \mathrm{mg}=$ cell protein) was reduced in comparison with controls $(34 \cdot 0 \pm 10 \cdot 1$ (SD) $\mathrm{fmol} / \mathrm{mg}$ protein $\mathrm{n}=15)$. ${ }^{\circledR}$ These results favour $\mathrm{X}$ linked inheritance of CAI and $\mathrm{X}$ inactivation at the androgen receptor $\vec{\otimes}$

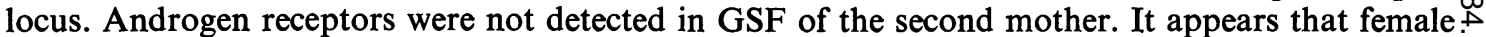
carriers of CAI could be detected by decreased $5 \alpha$-dihydrotestosterone binding in GSF.

Androgen receptor activity was also undetectable in non-genital skin fibroblasts (NGSF) from $\sum_{3}$ the second mother and two further CAI patients. However, in 1 in 10 control NGSF lines androgen $\overline{0}$ receptor activity was at the lower limit of assay sensitivity (1 to $2 \mathrm{fmol} / \mathrm{mg}$ protein) demonstrating $\frac{\otimes}{\varnothing}$ that NGSF may not be reliable for family studies of androgen receptor deficiency.

Patients with testicular feminisation (CAI; complete androgen insensitivity) have been shown to lack a functional androgen receptor protein on the basis of deficient binding of $5 \alpha$-dihydrotestosterone (DHT) in their cultured skin fibroblasts. ${ }^{1-3}$ The synthesis of the androgen receptor appears to be specified by an $\mathrm{X}$ chromosomal gene, consistent with the pattern of inheritance of CAI. ${ }^{45}$ About one-third of cases of CAI are reported to have an uninformative family history and have been presumed to represent new mutations. ${ }^{6}$ However, it has not previously been possible to test directly for heterozygosity in female relatives of CAI patients. Meyer et al $^{4}$ cloned wrist and pubic skin fibroblasts from an obligate carrier of CAI and provided evidence of $\mathrm{X}$ inactivation at the androgen receptor locus. Thus, it might be possible to detect female carriers of CAI on the basis of partly deficient DHT binding in their cultured fibroblasts. Recently, Donti et $a l^{7}$ reported that forearm skin fibroblasts from an obligate carrier of CAI had about one-half the DHT binding activity of control cells. However,

Received for publication 8 September 1983. Accepted for publication 27 October 1983. earlier studies indicated that non-genital skin fibroblasts were unsuitable for the analysis of DHT binding in CAI because of very low receptor levels in some control cell lines. ${ }^{3} 8$

We have analysed DHT binding in genital skin $\frac{0}{3}$ fibroblasts from the mothers of two sporadic cases of receptor deficient $\mathrm{CAI}$; a clear reduction of $\frac{\mathrm{O}}{3}$ binding was found in each subject. We also analysed non-genital skin fibroblasts from one of the mothers and a further two CAI patients. While specific DHT $\frac{D}{O}$ binding was undetectable in all three, the spread of results for control non-genital skin fibroblasts No prevented definite conclusions from being drawn.

\section{Materials and methods}

\section{GENITAL SKIN FIBROBLASTS}

Biopsies of labium majus skin were obtained, with consent, from the following.

Patient 1 was a 10 year old $46, \mathrm{XY}$ female with normal external genitalia and blind vagina. She had $\overline{0}$ presented at the age of 8 months with a left inguinal swelling containing a testis. Gynaecography failed to demonstrate either a uterus or fallopian tubes. At the age of 9 an HCG stimulation test was per178 
formed (1500 units daily for 4 days): basal plasma testosterone was $0.6 \mathrm{nmol} / 1$ rising to $4.1 \mathrm{nmol} / 1$ on day 4 (normal). Post-stimulation plasma androstenedione was $3 \cdot 2 \mathrm{nmol} / 1$ (normal). Family history is negative and the patient has two normal sisters.

Mother 1. The mother of patient 1 was a normal female with sparse axillary and pubic hair.

Patient 2 was a 21 year old $46, \mathrm{XY}$ female with typical complete testicular feminisation. She had normal external genitalia, a blind vagina, normal breast development, and no axillary and very sparse pubic hair. Family history is negative and the patient has one normal sister.

Mother 2. The mother of patient 2 was a normal female with sparse axillary and pubic hair.

Controls. Control subjects were chosen to examine the possibility that androgen receptor deficiency in fibroblasts might arise as a secondary consequence of the donor's hormonal state or degree of genital masculinisation. Thus, the controls included normal males and females, genetic males with a defined abnormality of steroid metabolism ( $5 \alpha$-reductase deficiency), which results in genital dysmorphogenesis, and genetic males in whom genital dysmorphogenesis occurred in association with multiple somatic abnormalities.

Genital skin biopsies (prepuce, scrotum, or labia) were obtained from the following controls: six normal males, three normal females, five males with $5 \alpha$-reductase deficiency (reference 9 and one unreported patient), and one $46, \mathrm{XY}$ male with multiple congenital abnormalities including perineal hypospadias.

\section{NON-GENITAL SKIN FIBROBLASTS}

Biopsies of upper arm skin were taken from the following.

\section{Mother 2.}

Patient 3 was a 23 year old $46, \mathrm{XY}$ female with typical complete testicular feminisation. She had no axillary hair and very sparse pubic hair. An older 46,XY 'sister' also had complete testicular feminisation.

Patient 4 was a 46,XY baby girl with normal female external genitalia and blind vagina, whose adult maternal half-sister $(46, X Y)$ had typical complete testicular feminisation.

Controls. Control cultures were established from upper arm or upper back skin of four normal males, two normal females, two of the male patients with $5 \alpha$-reductase deficiency (see above), a $46, X Y$ infant with female external genitalia and multiple congenital abnormalities, and also from fascia lata of a stillborn 46,XY baby with female external genitalia, $\alpha$-thalassaemia, and hydrops fetalis.
FIBROBLAST CULTURE AND

ASSAY OF DHT BINDING

The methods of fibroblast culture and androgen receptor assay have been described in detail. ${ }^{9}$ Briefly, fibroblast cultures were established from skin explants and maintained in Eagle's MEM containing $10 \%$ newborn calf serum. Patients' cell lines were established by colleagues in the Department of Medical Genetics and maintained for two passages in culture in our laboratory before use. Receptor and enzyme assays were carried out on cells between the 4 th and 15 th passages (corresponding to approximately 4 to 15 population doublings since the first subculture). For receptor assay a set of replicate cultures was established from each cell line by plating out about $2 \times 10^{5}$ cells per $60 \mathrm{~mm}$ plastic dish. After 7 days the cultures were maintained for 24 hours in MEM with $1 \%$ serum, then pairs of cultures were incubated for 30 minutes at $37^{\circ} \mathrm{C}$ with $5.0 \mathrm{ml}$ serum-free MEM containing ${ }^{3} \mathrm{H}$ DHT $\left(1 \alpha, 2 \alpha-{ }^{3} \mathrm{H}\right.$ or $1,2,4,5,6,7,-{ }^{3} \mathrm{H}$, specific activity 53 or $143 \mathrm{Ci} / \mathrm{mmol}$ ) at concentrations ranging from 0.05 to $3.2 \mathrm{nmol} / \mathrm{l}$. A parallel set of cultures contained ${ }^{3} \mathrm{H}$ DHT and unlabelled DHT $(100 \mathrm{nmol} / \mathrm{l})$ to assess non-specific binding of the hormone. After incubation the monolayers were washed extensively with phosphate buffered saline and the cells scraped from the dishes, centrifuged down, and extracted with chloroform:methanol (1:1 $\mathrm{v} / \mathrm{v}$ ) to extract cell-bound ${ }^{3} \mathrm{H}$ DHT. The radioactivity of the extracts was measured by liquid scintillation counting and the protein content of the extracted cell pellets was measured by the method of Lowry et al. ${ }^{10}$ Direct linear plots of the cellular contents of specifically bound ${ }^{3} \mathrm{H}$ DHT (fmol/mg protein) and the concentration of ${ }^{3} \mathrm{H}$ DHT free in the incubation medium were constructed to derive median estimates of Bmax, the cellular content of androgen receptors, and $\mathrm{Kd}$, the equilibrium dissociation constant of the ${ }^{3} \mathrm{H}$ DHT receptor complexes. ${ }^{11}$

\section{Results}

In experiments with either GSF or NGSF the results for the normal subjects and other controls overlapped completely. Therefore the controls were treated as a single group.

The cellular content of androgen receptors (Bmax) and the equilibrium dissociation constants of DHT receptor complexes at $37^{\circ} \mathrm{C}(\mathrm{Kd})$ are shown in the table. The mean $\mathrm{Bmax}( \pm \mathrm{SD})$ in 15 lines of control GSF was $34 \cdot 0 \pm 10 \cdot 1 \mathrm{fmol} / \mathrm{mg}$ total cell protein, and the mean value of $\mathrm{Kd}( \pm \mathrm{SD})$ was 0.27 $\pm 0 \cdot 22 \mathrm{nmol} / 1$. Repeated estimations at five different subcultures in one control GSF line gave $\mathrm{Bmax}=$ $34.7 \pm 7.17(\mathrm{SD})$ and $\mathrm{Kd}=0.30 \pm 0.12(\mathrm{SD})$. 
TABLE Specific binding of ${ }^{3} \mathrm{H} \mathrm{DHT}$ in fibroblasts from genital (GSF) and non-genital (NGSF) skin.

\begin{tabular}{lll}
\hline & Bmax (fmol/mg protein) & $K d(\mathrm{nmol} / \mathrm{l})$ \\
\hline Control GSF (n=15) & $34.0 \pm 10.1$ & $0.27 \pm 0.22$ \\
Patient 1 GSF & $<2$ & $\mathrm{Nm}$ \\
Mother 1 GSF & 8.5 & 0.90 \\
Patient 2 GSF & $<2$ & $\mathrm{Nm}$ \\
Mother 2 GSF & $<2$ & $\mathrm{Nm}$ \\
Control NGSF $(\mathrm{n}=10)$ & $9.98 \pm 4.89$ & $0.29 \pm 0.15$ \\
Mother 2 NGSF & $<2$ & $\mathrm{Nm}$ \\
Patient 3 NGSF & $<2$ & $\mathrm{Nm}$ \\
Patient 4 NGSF & $<2$ & $\mathrm{Nm}$ \\
\hline
\end{tabular}

$\mathrm{Bmax}=$ cellular content of androgen receptors.

$\mathrm{Kd}=$ equilibrium dissociation constant of ${ }^{3} \mathrm{H}$ DHT-receptor complexes at $37^{\circ} \mathrm{C}$ in intact cells. Control results are means $\pm S D$. $\mathrm{Nm}=$ not measurable.

Androgen receptors were not detected (Bmax less than 1 to $2 \mathrm{fmol} / \mathrm{mg}$ protein) in GSF from patients 1 and 2 and mother 2. A low receptor content was measured in GSF of mother 1 (Bmax $8.5 \mathrm{fmol} / \mathrm{mg}$ protein); $\mathrm{Kd}$ was high $(0.90 \mathrm{nmol} / 1)$. Androgen receptors were not detected in NGSF of patients 3 and 4 or mother 2. However, the mean value of Bmax in 10 control NGSF lines $(9.98 \pm 4.89$ (SD) $\mathrm{fmol} / \mathrm{mg}$ protein) was less than in GSF, and in one NGSF line from a normal male Bmax (1.89 $\mathrm{fmol} / \mathrm{mg}$ protein) was at the limit of assay sensitivity.

\section{Discussion}

Our failure to detect androgen receptors in skin fibroblasts of any of the four patients indicates that they have the receptor deficient form of complete androgen insensitivity, ${ }^{1-3}$ although caution is needed in interpreting results from NGSF (see below).

Deficient DHT binding in GSF of mothers 1 and 2 indicates that female carriers of receptor deficient CAI could be detected by receptor assays on GSF. Androgen receptors were detected but at a reduced level in GSF of mother 1, providing further evidence for $\mathrm{X}$ linked recessive inheritance of $\mathrm{CAI}$ and random $\mathrm{X}$ inactivation at the androgen receptor locus. ${ }^{45} 7$ A likely explanation of undetectably low androgen receptors in GSF from mother 2 is that the culture was derived mainly from cells carrying the mutant androgen receptor allele on the active $\mathrm{X}$ chromosome.

Undetectable DHT binding in NGSF of mother 2 is consistent with results from her GSF. Similarly the androgen receptor deficiency in NGSF of patients 3 and 4 is consistent with the clinical evidence of androgen insensitivity in their families. For family studies, potential carrier relatives of patients with CAI may be less willing to undergo biopsy of skin from a genital than another body site. However, assays on NGSF must be treated with caution because of the possible occurrence of $\stackrel{+}{\rightarrow}$ very low receptor levels in normal controls (1 in $10 \stackrel{\overrightarrow{\mathrm{s}}}{\mathrm{s}}$ in this study). In contrast, Donti et $a^{7}$ found higho values of Bmax in five control NGSF lines and $\frac{0}{5}$ reduced Bmax in NGSF from an obligate carrier of $\frac{\bar{c}}{\bar{\omega}}$ CAI. Whether these differences reflect heterogeneity $\widetilde{\Phi}$ of NGSF isolated in various laboratories requires further study.

It is interesting that both mothers 1 and 2 were $\overrightarrow{0}$ suspected of being heterozygotes by their sparse pubic $\overrightarrow{\vec{H}}$ and axillary hair, as might be expected from the ${ }_{\sigma}^{\omega}$ clonal origin of individual hair follicles. ${ }^{12}$ Although there are no generally accepted clinical criteria for identifying carriers of CAI, abnormalities ranging $\underset{T}{N}$ from reduced sexual hair to late onset of menarche $\omega$ have been noted in the mothers of some CAI $\vec{v}$ patients. ${ }^{1314}$ The occurrence of reduced DHT $\infty$ binding in GSF with sparse sexual hair in mothers 1 and 2 suggests that a quantitative study of andro- gen dependent sexual hair patterns might provide $\mathrm{a} \subseteq$ basis for the clinical recognition of heterozygosity in $\overparen{\nabla}$ female relatives of CAI patients.

Professor M A Ferguson-Smith and staff of the University Department of Medical Genetics, Royal Hospital for Sick Children, Yorkhill, Glasgow, provided invaluable help with cell culture and storage, as did Mr P Ferry of the University Depart- $\frac{\mathbb{Q}}{\square}$ ment of Biochemistry. Dr G Priestly provided some $\stackrel{2}{\Rightarrow}$ of the control NGSF lines. Mrs S Hill helped with $\frac{0}{3}$ some of the analyses. The work was supported by grants from the MRC and SHHD.

\section{References}

1 Keenan BS, Meyer WJ, Hadjian AJ, Jones HW, Migeon CJ. Syndrome of androgen insensitivity in man: absence of $5 \alpha$-dihydrotestosterone binding protein in skin $\mathrm{O}$ fibroblasts. J Clin Endocrinol Metab 1974;38:1143-6.

2 Griffin JE, Punyashthiti K, Wilson JD. Dihydrotesto- 0 sterone binding by cultured fibroblasts. Comparison of cells from control subjects and from patients with $\frac{D}{O}$ hereditary male pseudohermaphroditism due to androgen resistance. J Clin Invest 1976;57:1342-51.

3 Kaufman M, Straisfeld C, Pinsky L. Male pseudo- o hermaphroditism presumably due to target organ $N$ unresponsiveness to androgens. Deficient $5 \alpha$-dihydrotestosterone binding in cultured skin fibroblasts. J Clin $\omega$ Invest 1976;58:345-50.

4 Meyer WJ, Migeon BR, Migeon CJ. Locus on human $\mathrm{X}$-chromosome for dihydrotestosterone receptor and androgen insensitivity. Proc Natl Acad Sci USA 1975; 72:1469-72.

5 Migeon BR, Brown TR, Axelman J, Migeon CJ. Studies T of the locus for androgen receptor: localisation on the human $\mathrm{X}$ chromosome and evidence for homology with $\mathbb{D}$ the Tfm locus in the mouse. Proc Natl Acad Sci USA $1981 ; 78: 6339-43$.

- Griffin JE, Wilson JD. The syndromes of androgen resistance. N Engl J Med 1980;302:198-209. 
7 Donti E, Nicoletti I, Filipponi P, Venti G, Bocchini V, Santeusanio F. DHT-receptor in cultured human fibroblasts: binding study in a family with androgen insensitivity (complete testicular feminisation). J Med Genet 1982;19:349-53.

8 Herfert J, Wienker TF, Ropers HH. The presence of androgen binding receptors in genital and non-genital skin fibroblasts. Hum Genet 1980;53:271-3.

9 Hodgins MB. Binding of androgens in $5 \alpha$-reductase deficient human genital fibroblasts: inhibition by progesterone and its metabolites.J Endocrinol 1982;94:415-27.

10 Lowry OH, Rosebrough NJ, Farr AL, Randall RJ. Protein measurement with the Folin phenol reagent. J Biol Chem 1951;193:265-75.

11 Cornish-Bowden A, Eisenthal R. Estimation of Michaelis constant and maximum velocity from the direct linear plot. Biochim Biophys Acta 1978;523:268-72.
12 Gartler SM, Gandini E, Angioni G, Argiolas N. Glucose6-phosphate dehydrogenase mosaicism: utilization as a tracer in the study of the development of hair root cells. Ann Hum Genet 1969;33:171-6.

13 Pinsky L. The nosology of male pseudohermaphroditism due to androgen insensitivity. Birth Defects 1978;XIV (6c):73-95.

14 McKusick VA. Mendelian inheritance in man. 5th ed. Baltimore, London: Johns Hopkins University Press, 1978:802.

Correspondence and requests for reprints to Dr M B Hodgins, Department of Dermatology, University of Glasgow, Anderson College Building, Dumbarton Road, Glasgow G11 6NU. 